\title{
Usability Laman Penerimaan Mahasiswa Baru UNNES
}

\author{
Wahyu Hardyanto', Aryono Adhi' ${ }^{2}$, Aji Purwinarko ${ }^{3}$ \\ ${ }^{1,2}$ Jurusan Fisika, FMIPA, Universitas Negeri Semarang \\ ${ }^{3}$ Jurusan Ilmu Komputer, FMIPA, Universitas Negeri Semarang \\ Email: 'hardy@mail.unnes.ac.id, ${ }^{2}$ aryono_adhi@yahoo.com, ${ }^{3}$ aji.purwinarko@mail.unnes.ac.id
}

\begin{abstract}
Abstrak
Salah satu jalur penjaringan mahasiswa baru Universitas Negeri Semarang (UNNES) adalah melalui Seleksi Nasional Masuk Perguruan Tinggi Negeri (SNMPTN). Mekanisme seleksi melalui SNMPTN didesain dengan berbagai kemudahan karena berbasis laman yaitu melalui http://penerimaan.unnes.ac.id. Terdapat fenomena yang menarik terkait dengan kecenderungan jumlah pendaftar mahasiswa baru UNNES yang perlu diteliti menyangkut usability laman http://penerimaan.unnes.ac.id/. Hasil analisis data peminat SNMPTN dan SPMU UNNES selama lima periode terakhir terhadap jumlah mahasiswa yang diterima memperlihatkan jumlah penerimaan mahasiswa UNNES lebih besar berasal dari peminat SPMU dibandingkan dengan peminat SNMPTN. Hal tersebut menunjukkan usability laman http://penerimaan.unnes.ac.id/ optimal.
\end{abstract}

Kata Kunci: UNNES , SNMPTN, usability laman.

\section{PENDAHULUAN}

UNNES merupakan salah satu perguruan tinggi di lingkungan Kemendikbud Dikti yang mempunyai visi menjadi universitas konservasi, bertaraf internasional, yang sehat, unggul, dan sejahtera pada tahun 2020. Misi UNNES adalah menyelenggarakan dan mengembangkan pendidikan yang unggul dan bertaraf internasional di bidang kependidikan dan non kependidikan, mengembangkan, menciptakan, dan/atau menyebarluaskan ilmu pengetahuan, teknologi, seni, dan olahraga, yang bermakna dan bermanfaat, mengembangkan kebudayaan dan peradaban bangsa yang menjunjung tinggi nilai nilai konservasi.

UNNES sebagai perguruan tinggi bertujuan menghasilkan tenaga akademik, profesi, dan vokasi yang memiliki kompetensi unggul, menghasilkan karya ilmu pengetahuan, teknologi, seni, dan olah raga yang bermakna dan bermanfaat, serta menghasilkan kebudayaan dan peradaban bangsa yang berlandaskan nilai-nilai konservasi.

UNNES merupakan salah satu institusi lingkup Kemenristek Dikti yang juga telah memiliki jaringan laman yang dikelola secara swadaya melalui laman www.unnes.ac.id. Informasi yang tersaji meliputi aspek akademik dan non akademik serta kelembagaan di lingkungan UNNES. Beragam kegiatan akademik dan non akademik serta kelembagaan UNNES telah disebar luaskan melalui laman, sehingga 
bisa diakses secara luas mendunia. Fasilitas ini juga dapat dimanfaatkan untuk mempromosikan keunggulan UNNES terutama dalam kaitannya untuk menjaring mahasiswa baru.

Salah satu jalur penjaringan mahasiswa baru adalah melalui SNMPTN. UNNES termasuk salah satu perguruan tinggi yang melaksanakan proses seleksi mahasiswa baru melalui SNMPTN. Mekanisme seleksi melalui SNMPTN didesain dengan berbagai kemudahan. Seluruh proses ini bahkan tanpa biaya sedikit pun atau gratis, karena berbasis laman yaitu melalui http://penerimaan.unnes.ac.id/.

Tahun 2012 jumlah pendaftar SNMPTN mencapai mencapai 70.491 tanpa membedakan UNNES sebagai pilihan pertama ataupun pilihan kedua. Data yang didapatkan menunjukkan pada tahun 2013 jumlah pendaftar SNMPTN mencapai mencapai 99.670 orang terbagi atas 52.384 pendaftar yang menempatkan perguruan tinggi itu sebagai pilihan pertama, dan sisanya pilihan kedua. Tahun 2014 jumlah pendaftar SNMPTN mencapai mencapai 76.576 tanpa membedakan UNNES sebagai pilihan pertama ataupun pilihan kedua.

Data yang disajikan memperlihatkan fenomena menarik mengenai kecenderungan jumlah pendaftar yang menempatkan UNNES sebagai pilihan pertama dan kedua. Hal tersebut dipandang merupakan permasalahan menarik untuk dianalisis khususnya terkait dengan keberadaan laman http://penerimaan.unnes.ac.id. Terdapat beberapa hal yang perlu dicermati. Pertama mengapa terjadi pendaftar SNMPTN yang tidak konsisten menentukan UNNES sebagai pilihan pertama, kedua evaluasi menyangkut usability keberadaan laman http://penerimaan.unnes.ac.id/ terhadap penerimaan mahasiswa baru UNNES dan relevansinya dengan jumlah peminat UNNES yang tergambar melalui http://penerimaan.unnes.ac.id, dan ketiga usability http://penerimaan.unnes.ac.id/ terhadap penerimaan mahasiswa baru UNNES dan relevansinya dengan jumlah peminat UNNES yang tergambar melalui http://penerimaan.unnes.ac.id.

Asrori [1] menyatakan https://akademik.unnes.ac.id/index.php yang merupakan bagian dari laman www.unnes.ac.id bermanfaat nyata untuk melihat data yang diminta khususnya data akademik cepat sekali, untuk mahasiswa sendiri menjadi lebih cepat karena dihubungkan dengan internet, efisien karena tidak perlu datang ke kampus tetapi cukup dilakukan dirumah ataupun melalui internet dimanapun mereka berada kecuali mereka mempunyai masalah yang harus diselesaikan dikampus. Mahasiswa dapat secara langsung mengetahui nilai pada setiap akhir semester karena dapat diakses secara online, artinya mahasiswa dapat secara online melalui komputer nilai yang dimilikinya, kemudian mahasiswa setiap saat bisa melihat perkembangan IP dan IPK nya dan mahasiswa juga dapat melihat mata kuliah apa yang dapat diambil selanjutnya, salah satunya jatah KRS semester depan dapat diperkirakan sebelumnya tanpa harus konsultasi terlebih dahulu ke dosen wali.

Asrori [1] mendapatkan keberadaan Sikadu melalui https://akademik.unnes.ac.id/index.php bagi organisasi atau UNNES secara keseluruhan sangat bermanfaat, antara lain pada aspek sistem perencanaan KRSnya, nilai, ketepatan waktu ujian dan ketepatan pengumpulan soal ujian semakin baik. 
Terbangunnya sistem informasi tersebut yang mulanya untuk memperbaiki sistem yang sangat rawan antara lain adanya kebocoran, perubahan dan benar-benar dapat dimonitor keamanannya nilai termasuk didalamnya mengenai kriteria pengambilan mata kuliah oleh masing-masing mahasiswa. Selain itu dengan sistem yang sekarang berjalan tersebut Beban Kerja Dosen yang merupakan form yang harus diisi setiap dosen pada setiap awal semester, sudah dapat langsung diketahui bahwa dosen yang bersangkutan mempunyai beban kredit/tugas yang sudah memenuhi syarat atau kelebihan dan sebagainya.

Pemanfaatan https://akademik.unnes.ac.id/index.php berpengaruh positif signifikan terhadap kinerja individual. Hal ini menunjukkan pemanfaatan https://akademik.unnes.ac.id/index.php dengan intensitas yang tinggi dapat meningkatkan kinerja individual. Kemudahan penggunaan Sikadu melalui https://akademik.unnes.ac.id/index.php tidak memoderasi pengaruh pemanfaatan Sikadu terhadap kinerja individual, sehingga dapat disimpulkan bahwa variabel kemudahan penggunaan Sikadu bukan variabel moderating. Hal ini menunjukkan bahwa mudah atau sulitnya penggunaan Sikadu tidak mempengaruhi pemanfaatan Sikadu terhadap kinerja individual [2].

Secara empiris ditemukan fakta bahwa untuk menerima teknologi informasi terkait dengan implementasi Sikadu UNNES tidak harus dipikirkan terlebih dahulu apakah teknologi informasi tersebut memberikan manfaat atau tidak namun merupakan suatu keharusan dan kebutuhan sehingga teknologi informasi tersebut harus dianggap mudah untuk digunakan. Dan untuk saat ini teknologi informasi sudah dianggap sesuatu yang mudah, karena sudah seringnya dilakukan pelatihan-pelatihan yang diperuntukkan dalam peningkatan keterampilan penggunaan teknologi informasi oleh dosen, seperti latihan mengoperasikan SPSS, membuat power point, mengoperasikan internet, membuat email, mengunggah materi ajar di internet [3].

Suatu informasi melalui media massa yang populer menggunakan bahasa jurnalistik yang tetap berpedoman pada bahasa Indonesia yang baku. Diketahui bahwa bahasa jurnalistik memiliki sifat fleksibel artinya mampu dipahami oleh berbagai kalangan yang membacanya. Tidak dapat dipungkiri bahwa penyampaian suatu materi pada laman bisa menggunakan metode penyajian dalam bahasa jurnalistik.

Evaluasi diperlukan untuk mengetahui sejauh mana materi yang disebarluaskan dapat diterima oleh pengguna. Evaluasi dapat dilakukan untuk tahap awal dengan mempelajari seberapa jumlah pengunjung laman dan perkembangannya dalam kurun waktu tertentu. Pengguna akan melakukan kunjungan terhadap suatu situs tertentu termasuk laman sesuai dengan keperluan dan kebutuhan masing-masing. Dengan jaringan yang sangat luas melalui internet tentu sangat beragam keperluan dan kebutuhan pengguna. Selain materi yang diperlukan, saat ini pengguna akan membutuhkan sajian yang menarik. Jika ingin mengamati lebih jauh mengenai sajian menarik yang diinginkan oleh pengunjung, memerlukan suatu kajian tersendiri dan mendalam [4].

Hardyanto, W., et al. [5] melakukan penelitian awal mengenai sistem informasi di universitas ' $\mathrm{X}$ '. Penelitian awal ini selanjutnya akan menjadi acuan penelitian SI 
dengan Pendekatan Technology Acceptance Model (TAM) [6]. Metode yang dilakukan pada paper ini melalui wawancara/in dept interview, dokumentasi dan kuisioner. Hasil penelitian awal yang didapatkan menunjukkan SI di universitas ' $\mathrm{X}$ ' harus diperbaiki untuk dapat optimal dalam melayani kebutuhan stakeholder.

Hardyanto, W., et al. [7] melakukan kajian terhadap Sistem Informasi Akademik Terpadu (Sikadu) UNNES dengan pendekatan Technology Acceptance Model (TAM) yang tujuannya adalah mendapatkan akuntabilitas aplikasi Sikadu di UNNES dengan mengambil sampling Program Pascasarjana UNNES. Metode yang dilakukan pada paper ini melalui wawancara/in dept interview, dokumentasi dan kuisioner. Analisis dilakukan dengan menggunakan analisis Structural Equation Modeling (SEM) berbasis kovarian AMOS (Analysis of Moment Structures) [8]. Hasil yang didapatkan secara keseluruhan, Knowledge of Search Domain tidak berpengaruh terhadap Perceived Ease of Use. Namun demikian, CMIN/DF memenuhi syarat, karena mempunyai nilai $\leq 2$.

Menurut CNET/Builder ada 7 kriteria yang menentukan sebuah laman site termasuk laman site yang baik/tidak [4], yaitu:

\section{a) Usability}

Jacob Nielsen menyatakan usability adalah dapatkah seorang user menemukan cara untuk menggunakan laman site tersebut dengan efektif (doing things right). Masih menurut Jacob, usability memiliki 5 karakteristik (1) mudah untuk dipelajari, (2) efisien untuk digunakan, (3) mudah untuk diingat; (4) tingkat frekuensi kesalahan, dan (5) tingkat kepuasan pemakai.

b) Sistem navigasi

Navigasi yang mudah dipahami oleh pengunjung secara keseluruhan.

c) Graphic Design

Pemilihan grafis, tataletak, warna, bentuk maupun typografi yang menarik visual pengunjung untuk menjelajahi laman site.

d) Content

Isi/konten yang bermanfaat ('Content is king, but without good design. Content is a naked king'), kecuali laman site eksperimental/show off.

e) Kompatibilitas

Seberapa luas sebuah laman site didukung kompabilitas peralatan yang ada, misalnya browser dengan berbagai plug-in-nya (IE, Mozilla, Opera, Netscape, Lynx, Avant, Maxthon dan masih banyak lagi dengan berbagai versi dan plug-in nya).

\section{f) Loading time}

Waktu panggil (loading time), walaupun ada banyak faktor yang akan mempengaruhi waktu panggil (loading time) laman site yang akan kita buka, diantaranya: besar bandwith/koneksi pengakses, kondisi laman server pada saat diakses, dan aplikasi yang digunakan dalam membangun laman site. Terdapat waktu 8 detik pertama untuk meyakinkan pengunjung untuk meneruskan menjelajahi laman site atau menutup 
browser dan pergi ke laman site lain. Oleh karena itu, letakkan 'sesuatu' di 8 detik pertama tersebut yang bisa menarik perhatian pengunjung. Hint: ukuran sebuah halaman laman html dengan image di dalamnya (tanpa flash) adalah kurang lebih 50$60 \mathrm{~kb}$.

g) Functionality

Ini akan melibatkan programmer dengan script-scriptnya, misal PHP, ASP, Java, CGI dsb, untuk menciptakan sebuah laman site yang dinamis, interaktif dan 'hidup' yang bisa mengajak pengunjung berkomunikasi secara langsung. Seberapa baik sebuah laman site bekerja dari aspek teknologinya.

Satu hal lagi aspek yang tidak boleh kita lupakan adalah accesibility, yaitu memaksimalkan penggunaan sebuah content ketika satu/lebih indera kita dimatikan/dikurangi (khususnya mata), ingat bahwa mungkin saja pengunjung laman site kita adalah orang yang memiliki kekurangan secara fisik (Accesibility Checklist Recomendationnya W3C ).

\section{METODE}

Analisis dilakukan dengan menggunakan data peminat yang terdokumentasikan di BPTIK UNNES untuk kemudian dipetakan sehingga akan didapatkan korelasi yang signifikan.

1) Jumlah peminat di www.unnes.ac.id selama kurun waktu dibukanya SNMPTN dan SPMU selama lima periode terakhir.

2) Jumlah peminat di http://.unnes.ac.id/berita/informasi-snmptn dan http://spmu.unnes.ac.id/ selama kurun waktu dibukanya SNMPTN dan SPMU selama lima periode terakhir.

3) Jumlah peminat di http://penerimaan.unnes.ac.id/ selama kurun waktu dibukanya SNMPTN dan SPMU selama lima periode terakhir.

Teknik analisis data yang digunakan dalam paper ini yaitu teknik analisis statistik regresi linier multivariat.

\section{HASIL DAN PEMBAHASAN}

Data peminat SNMPTN dan SPMU UNNES selama lima periode terakhir diperlihatkan pada Tabel 1 .

Tabel 1. Peminat SNMPTN dan SPMU

\begin{tabular}{cccc}
\hline Tahun & $\begin{array}{l}\text { Mahasiswa } \\
\text { Diterima }\end{array}$ & $\begin{array}{l}\text { Peminat } \\
\text { SPMU }\end{array}$ & $\begin{array}{l}\text { Peminat } \\
\text { SNMPTN }\end{array}$ \\
\hline 2010 & 5214 & 42785 & 12609 \\
2011 & 7200 & 13781 & 61635 \\
2012 & 7289 & 15964 & 70491 \\
2013 & 6981 & 13591 & 99670 \\
2014 & 6254 & 17713 & 76576 \\
\hline
\end{tabular}

Berdasarkan hasil analisis data pada Tabel 1 didapatkan hasil sebagai berikut. 
Tabel 2. Summary output

\begin{tabular}{lr}
\hline \multicolumn{2}{c}{ Regression Statistics } \\
\hline Multiple R & 0.988032943 \\
$R$ Square & 0.976209096 \\
Adjusted R Square & 0.634945462 \\
Standard Error & 1320.864743 \\
Observations & 5 \\
\hline
\end{tabular}

Berdasarkan Tabel 2, terlihat bahwa nilai koefisien determinasi R-Square $=0.972$ $(97,2 \%)$. Ini menunjukkan bahwa sebesar (97,2\% variasi variabel dependent (Y) dapat dijelaskan oleh 2 variabel independent (X1 dan X2), artinya pengaruh variabel independen terhadap perubahan variabel dependen adalah $97,2 \%$, sedangkan sisanya sebesar 2,8\% dipengaruhi oleh variabel lain selain variabel independen X1 dan X2.

Tabel 3. Anova

\begin{tabular}{lrrrrr}
\hline & $d f$ & \multicolumn{1}{c}{$S S$} & \multicolumn{1}{c}{$M S$} & \multicolumn{1}{c}{$F$} & Significance $F$ \\
\hline Regression & 2 & $2.15 \mathrm{E}+08$ & $1.07 \mathrm{E}+08$ & 61.54931 & 0.015987 \\
Residual & 3 & 5234051 & 1744684 & & \\
Total & 5 & $2.2 \mathrm{E}+08$ & & & \\
\hline
\end{tabular}

Dari Tabel 3 didapat nilai $\mathrm{F}=61,54$ yang dapat digunakan untuk melakukan uji hipotesis atau F-test dalam memprediksi kontribusi variabel-variabel independent (X1 dan X2) terhadap variabel dependent (Y).

Hypothesis:

$\mathrm{H} 0: \beta 1=\beta 2=0$

H1: Minimal satu dari dua variabel tidak sama dengan nol

Dengan menentukan level of significant $=5 \%(0,05)$ dan degree of freedom untuk df1 $=2$ dan df $2=3$, maka didapat dari tabel F-tabel $=9.5521$.

Oleh karena F-hitung $=61,54>$ F-tabel $(0,05)=9.5521$, maka H0 ditolak dan H1 diterima. Kesimpulannya, bahwa variabel independent (X1 dan X2) dengan signifikan memberikan kontribusi terhadap variabel dependent.

Tabel 4. Coefficients

\begin{tabular}{rcccccc}
\hline Coefficients & $\begin{array}{c}\text { Standard } \\
\text { Error }\end{array}$ & tStat & P-value & $\begin{array}{c}\text { Lower } \\
95 \%\end{array}$ & $\begin{array}{c}\text { Upper } \\
95 \%\end{array}$ & $\begin{array}{c}\text { Lower } \\
95.0 \%\end{array}$ \\
\hline 0 & \#N/A & \#N/A & \#N/A & \#N/A & \#N/A & \#N/A \\
0.107697766 & 0.032327 & 3.331 .541 & 0.044668 & 0.00482 & 0.210576 & 0.00482 \\
0.066139385 & 0.010828 & 6.108 .418 & 0.008816 & 0.031681 & 0.100598 & 0.031681 \\
\hline
\end{tabular}

Berdasarkan Tabel 4, terlihat bahwa nilai p-value untuk X1 $<0.05$, dengan besar koefisien b1 $=0.107697765704214$ artinya variabel $\mathrm{X} 1$ mempengaruhi variabel $\mathrm{Y}$ secara signifikan dengan setiap kenaikan 1 satuan variabel X1 akan meningkatkan variabel Y sbesar 0.107697765704214 satuan. Kemudian, nilai p-value untuk X2 < 
0.05, dengan besar koefisien $b 1=0.0 .0661393846455803$ artinya variabel $\mathrm{X} 2$ mempengaruhi variabel $\mathrm{Y}$ secara signifikan dengan setiap kenaikan 1 satuan variabel X2 akan meningkatkan variabel Y sbesar 0.0661393846455803 satuan. Sehingga, didapatkan persamaan $\mathrm{Y}=0.107697765704214$ SPMU +0.0661393846455803 SNMPTN.

\section{SIMPULAN}

Hasil analisis data peminat SNMPTN dan SPMU Universitas Negeri Semarang selama lima periode terakhir terhadap jumlah mahasiswa yang diterima diperlihatkan oleh persamaan $\mathrm{Y}=0.107697765704214$ SPMU +0.0661393846455803 SNMPTN. Berdasarkan persamaan tersebut, jumlah penerimaah mahasiswa Universitas Negeri Semarang lebih besar dipengaruhi oleh peminat SPMU dibandingkan dengan peminat SNMPTN.

\section{REFERENSI}

[1] Asrori. 2010. Pengembangan Sistem Informasi Akademik Terpadu (Sikadu) Berbasis Perilaku Pengguna Dosen untuk Meningkatkan Kinerja Akademik UNNES. Vol. 5(1): $33-42$.

[2] Agustiani, N.H.. 2010. Pengaruh Pemanfaatan Sistem Informasi Akademik Terpadu (Sikadu) Terhadap Kinerja Individual Dengan Kemudahan Penggunaan Sebagai Variabel Moderating (Tesis). Universitas Diponegoro, Semarang.

[3] Palupiningdyah dan Widiyanto. 2011. Strategi Peningkatan Kualitas Pembelajaran Melalui Pemanfaatan Increasing Learning Motivation (ILMO). Ekplanasi. Vol 6(2), Edisi September 2011.

[4] Lukito. 2009. Pemanfaatan TI di Perguruan Tinggi. http://lukito.staff.ugm.ac.id/files/2013/02/Pemanfaatan-TI-di-PerguruanTinggi-Final.pdf [20 Maret 2015].

[5] Hardyanto. W. 2012. ICT and Institutional Learning: UNNES Experience. Prosiding Seminar Nasional Cakrawala Pembelajaran Berkualitas di Indonesia. UNNES Semarang.

[6] Hong, S., Thong, J.Y.L., and Tam, K.Y. 2006. Understanding Continued Information Technology Usage Behavior: A Comparison of Three Models in The Context of Mobile Internet. Decision Support Systems. Vol. 42(3):1819-1834.

[7] Hardyanto, W. Aryono A., and Purwinarko, A. 2015. Research on Sistem Informasi Akademik Terpadu (SIKADU) Unnes using Technology Acceptance Model (TAM). ICST UGM Yogyakarta. 2015.

[8] Hong, S., Thong, J.Y.L., Moon, J.-Y., and Tam, K.-Y. 2008. Understanding the Behavior of Mobile Data Services Consumers. Information Systems Frontiers. Vol. 10(4): 431-445. 